Research Article

\title{
Radiological Safety Analysis for a Hypothetical Accident of a Generic VVER-1000 Nuclear Power Plant
}

\author{
K. Gyamfi ${ }^{1,}{ }^{1,2}$ S. A. Birikorang, ${ }^{2,3}$ E. Ampomah-Amoako, ${ }^{2,3}$ and J. J. Fletcher ${ }^{2}$ \\ ${ }^{1}$ Ghana Atomic Energy Commission, National Nuclear Research Institute, P.O. Box LG 80, Legon, Accra, Ghana \\ ${ }^{2}$ Graduate School of Nuclear and Allied Sciences, University of Ghana, Legon, Accra, Ghana \\ ${ }^{3}$ Nuclear Regulatory Authority, P.O. Box AE 50, Atomic Energy, Accra, Ghana \\ Correspondence should be addressed to K. Gyamfi; kingbascillus@yahoo.co.uk
}

Received 15 August 2019; Revised 4 November 2019; Accepted 10 December 2019; Published 21 January 2020

Academic Editor: Leon Cizelj

Copyright ( $\odot 2020$ K. Gyamfi et al. This is an open access article distributed under the Creative Commons Attribution License, which permits unrestricted use, distribution, and reproduction in any medium, provided the original work is properly cited.

\begin{abstract}
Atmospheric dispersion modelling and radiological safety analysis have been performed for a postulated accident scenario of a generic VVER-1000 nuclear power plant using the HotSpot Health Physics code. The total effective dose equivalent (TEDE), the respiratory time-integrated air concentration, and the ground deposition concentration are calculated considering site-specific meteorological conditions. The results show that the maximum TEDE and ground deposition concentration values of $3.69 E-01 \mathrm{~Sv}$ and $3.80 E+06 \mathrm{kBq} / \mathrm{m}^{2}$ occurred at downwind distance of $0.18 \mathrm{~km}$ from the release point. This maximum TEDE value is recorded within a distance where public occupation is restricted. The TEDE values at distances of $5.0 \mathrm{~km}$ and beyond where public occupation is likely to be found are far below the annual regulatory limits of $1 \mathrm{mSv}$ from public exposure in a year even in the event of worse accident scenario as set in IAEA Safety Standard No. GSR Part 3; no action related specifically to the public exposure is required. The released radionuclides might be transported to long distances but will not have any harmful effect on the public. The direction of the radionuclide emission from the release point is towards the north east. It is observed that the organ with the highest value of committed effective dose equivalent (CEDE) appears to be the thyroid. It was followed by the bone surface, lung, red marrow, and lower large intestine wall in order of decreasing CEDE value. Radionuclides including I-131, I-133, Sr-89, Cs-134, Ba-140, Xe-133, and Xe-135 were found to be the main contributors to the CEDE.
\end{abstract}

\section{Introduction}

Industrialization and economic growth have created an ever-increasing demand of electricity. This has made a lot of countries turn their attention to nuclear energy [1-3]. Ghana is among the many nonnuclear countries that have shown strong and consistent interest in including nuclear energy in their energy mix. Nuclear and radiological safety consideration is one key that is given great attention during the selection and siting of nuclear power plant (NPP) [4-6].

Radioactive dispersion analysis is typically employed to conduct risk assessment of the NPP at the chosen site and estimate the impact on the neighbouring population and environment in the case of a nuclear accident at the power plant. Radiological safety analysis for hypothetical accident offers a major input for the safety analysis of nuclear power plant, as far as the health and safety of human are concerned $[7,8]$.

The dose equivalent as a result of the radionuclides release from an accident could be external or internal to the human body. The total effective dose equivalent (TEDE) is the summation of the effective dose equivalent (EDE) as a result of external exposure from submersion, ground shine, and resuspension and the total committed effective dose equivalent (CEDE) as a result of internal exposure from inhalation. Thus, the TEDE gives a comprehensive expression of the collective dose from all applicable delivery pathways $[9,10]$.

This paper presents the atmospheric radioactive dispersion analysis from hypothetical accident of a generic VVER-1000 at a proposed site in Axim along the west coast of Ghana using HotSpot Health Physics code. 


\section{Description of HotSpot Health Physics Code}

The HotSpot Health Physics code was created by Lawrence Livermore National Laboratory (LLNL) in order to provide Health Physics personnel, emergency response personnel, and emergency planners with a fast, field-portable calculation tool for evaluating accidents involving radioactive materials. The atmospheric dispersion models used by HotSpot software are a first-order approximation of the radiation effects associated with the short-term atmospheric discharge of radioactive materials. In fact, they are designed for near-surface releases, short-range dispersion, and shortterm emission in unobstructed terrains and simple meteorological conditions. HotSpot estimates the dispersal of radioactive materials using the Gaussian model, since the adequacy of this model for making initial dispersion estimates or worst-case safety analyses has been tested and verified for many years [9].

HotSpot programs are reasonably accurate for a timely initial assessment. More importantly, HotSpot code produces a consistent output for the same input assumptions and minimizes the probability of errors associated with reading a graph incorrectly. This acute mode can be used for estimating the immediate radiological impact associated with high acute radiation doses [11]. The main advantages of GPM are short computation time, extensive validation, and worldwide acceptance [9].

The merit of employing HotSpot code in this research work is that the code is capable of estimating detailed accident condition, transport of radionuclides, and dose calculation after the accident through the use of detailed physical models.

The results of the Gaussian plume models are dependable within a factor of 2-4, for the short distances from the release point $[12,13]$. The HotSpot code does not give direct uncertainty associated with estimated results and is deterministic. When the same input parameters are used for different simulation scenarios, the same answer is acquired each time.

\section{Materials and Methods}

3.1. Site-Specific Conditions of the VVER-1000. Ghana is working extensively on the introduction of nuclear energy into the country's energy mix. It is very likely that Ghana's first nuclear power plant will be a VVER and will be built along the coast of the country. Axim, which is the chosen site for this study, is a coastal area located in the western region of Ghana with an elevation of $38 \mathrm{~m}$, lying on latitude of 4.86992 north and longitude of -2.24046 west. 10-year period (2008-2017) meteorological data were used for this study. The meteorological data of Axim indicate annual average wind speed of $1.5 \mathrm{~ms}^{-1}$ with an annual average temperature of $27.3^{\circ}$. The wind direction is mostly southwestern. The principal stability class that pertains in this area is the stability class A. The transport and dispersion of air pollutants are greatly influenced by the atmospheric stability. It can be defined as the atmospheric tendency to reduce or intensify vertical motion or, alternatively, to suppress or enhance existing turbulence [14]. It is related to the change of temperature with height (lapse rate) and also wind speed. The degree of stability of the atmosphere must be known to estimate the ability of atmosphere to disperse pollutants $[15,16]$.

3.2. Source Term and Accidental Release Scenario. The radiological consequence analysis of a generic VVER$1000 \mathrm{MW}$ core which was based on a design basis loss of coolant accident (LOCA) resulting in release of radionuclides from the reactor core to the atmosphere after passing through various retention barriers was performed. The study assessed a cold leg break in the primary coolant loop next to the reactor pressure vessel (RPV) to represent LOCA accident. A large release is only possible when many fuel rods are substantially damaged. The surest way this can realistically occur is by loss of water from the primary coolant system, consequently rendering the reactor core uncovered by water. This type of accident scenario helps to estimate the magnitude of health risk to public for any radiological release. This kind of accident scenario was adopted based on NRC probabilistic safety assessment (PSA), which defines it as the main contributor of fission product class termed as source term category (STC). The STC represents an average source term category for both the frequency and the consequence of the accident event [17].

In the scenario, it was postulated that one of the cold legs breaks in the primary coolant loop of VVER-1000 plant representing a LOCA accident leading to core degradation until failure of the reactor pressure vessel (RPV). The break of the primary coolant loop next to the RPV was assumed to be due to corrosion cutting coolant supply to the RPV increasing the temperature of the reactor's core. It was assumed that the incident resulted in a release of radionuclide to the reactor hall, which had its exhaust ventilation system and gas purge system turned off. As the operation team members tried to salvage the situation, radionuclide activity from the reactor's core escaped through the reactor building stack in the form of gas and particulate and then diffused into the atmosphere. The radionuclide released into atmosphere is transported downwind according to the site meteorology.

In estimating radiation safety of VVER-1000 NPP, ORIGEN 2.1 code was used to calculate the activity and photon flux of the fuel bundles during burn-up and the cooling time. The WIMS-ANL code was used for burn-up analysis since the library of the ORIGEN 2.1 code cross section data does not contain the VVER-100 fuel type. All factors related to the fuel geometry and the neutron spectrum have been treated in WIMS-ANL. Burn-up calculations of the fuel lattice cells were performed from the beginning up to the burn-up of about 55\% loss of U-235 for the fuel. The heavy nuclides of the fuel burn-up dependent microscopic cross sections were all collapsed from 69 energy groups to one energy group and later used in the ORIGEN 2.1 code for core depletion analysis to estimate the source term and the available radionuclides present in the fuel. The 
estimated depleted radionuclide of greater health consequence was used in the HotSpot code for dose estimation. Accident source term for the generic VVER-1000 is shown in Table 1. The total activity from the generated radionuclides was $1.11 E+16 \mathrm{~Bq}$.

3.3. HotSpot Simulation Procedure. The entire simulation methodology for the HotSpot 3.0 code is described by the flow chart in Figure 1.

To start the initial assessment of accidents involving release of radionuclides, the simulation was initiated by selecting the atmospheric dispersion model to be used from the main interface of the HotSpot code. In this work, the general plume under the dispersion model was selected, since it addresses the release of any radionuclide and also estimates downwind radiological impact following the release of radioactive material resulting from a short-term release (less than a few hours). The accident scenario being considered in this work was applied during the simulation. An input deck for the source term was developed and added to the source term library, which was then used as part of the input data of the Hotspot code for the calculation of radiological doses. The damage ratio and leak-path factor were both chosen to be 1.0 for a worst-case accident scenario. The effective release height of $65 \mathrm{~m}$ was specified in the source term model unit. In considering the meteorology unit, the HotSpot code requires inputs for atmospheric stability class, wind direction, and wind speed. The input specification for location coordinates and site topography are provided by the receptors model unit. The setup model unit was used in selecting source geometry (simple), radiological units (SI unit-Sievert, Gray, and $\mathrm{Bq}$ ), distance units (metric), terrain (standard: conservative option), DCF library (FGR 11), contour values (default code values), and breathing rate of $3.33 E-04 \mathrm{~m}^{3} \mathrm{~s}^{-1}$. The calculation results of the code are generated by the output model unit which gives the TEDE, $\mathrm{CEDE}$, and concentration values in text files, graphs, and contour plots.

The calculation of the HotSpot code considers all exposure pathways such as direct irradiation, inhalation, submersion, and ingestion comprising external exposure and internal exposure pathways.

\section{Results and Discussion}

4.1. TEDE Results and Analysis. The HotSpot code estimated radiation dose produced after the release based on the sitespecific meteorological condition. The TEDE, the ground deposition, and the respiratory time-integrated air concentration were calculated as a function of downwind distance as shown in Table 2. It can be seen from Figure 2 that the TEDE initially increases with increasing distance downwind, reaches the maximum value, and then decreases sharply. A similar Gaussian trend is shown in Figure 3 for the plume centreline ground deposition of radionuclides as a function of downwind distance. It can be realised from Table 2 and Figure 2 that the maximum TEDE is $3.69 \mathrm{E}-01 \mathrm{~Sv}$ and this occurs at the downwind distance of
TABLE 1: Accident source term for the generic VVER-1000.

\begin{tabular}{|c|c|}
\hline Nuclide & Activity (Bq) \\
\hline $\mathrm{Ba}-137 \mathrm{~m}$ & $5.98 E+13$ \\
\hline Ba-140 & $2.25 E+14$ \\
\hline Ce-144 & $5.78 E+12$ \\
\hline Cs-134 & $1.06 E+14$ \\
\hline Cs-136 & $1.89 E+13$ \\
\hline Cs-137 & $6.82 E+13$ \\
\hline Cs-138 & $5.28 E+11$ \\
\hline $\mathrm{I}-131$ & $4.69 E+14$ \\
\hline I-132 & $6.18 E+14$ \\
\hline I-133 & $7.66 E+14$ \\
\hline $\mathrm{I}-134$ & $8.88 E+12$ \\
\hline $\mathrm{I}-135$ & $4.03 E+14$ \\
\hline $\mathrm{Kr}-85$ & $3.42 E+13$ \\
\hline $\mathrm{Kr}-85 \mathrm{~m}$ & $2.13 E+14$ \\
\hline $\mathrm{Kr}-87$ & $3.79 E+13$ \\
\hline $\mathrm{Kr}-88$ & $3.36 E+14$ \\
\hline La-140 & $1.85 E+13$ \\
\hline Mo-99 & $7.15 E+12$ \\
\hline Np-239 & $1.03 E+14$ \\
\hline Pr-144 & $5.74 E+12$ \\
\hline $\operatorname{Pr}-144 m$ & $1.03 E+11$ \\
\hline $\mathrm{Pu}-239$ & $2.77 E+06$ \\
\hline $\mathrm{Rb}-88$ & $2.76 E+14$ \\
\hline Rh-103m & $5.32 E+12$ \\
\hline Rh-106 & $2.60 E+12$ \\
\hline Ru-103 & $5.38 E+12$ \\
\hline Ru-106 & $2.60 E+12$ \\
\hline $\mathrm{Sb}-127$ & $2.04 E+13$ \\
\hline Sb-129 & $3.46 E+13$ \\
\hline Sr-89 & $1.33 E+14$ \\
\hline Sr-90 & $1.15 E+13$ \\
\hline Sr-91 & $9.05 E+13$ \\
\hline Tc-99m & $7.02 E+12$ \\
\hline $\mathrm{Te}-127$ & $7.56 E+12$ \\
\hline $\mathrm{Te}-127 \mathrm{~m}$ & $7.72 E+09$ \\
\hline Te-129 & $4.76 E+13$ \\
\hline $\mathrm{Te}-129 \mathrm{~m}$ & $1.94 E+13$ \\
\hline $\mathrm{Te}-131$ & $8.11 E+12$ \\
\hline $\mathrm{Te}-131 \mathrm{~m}$ & $3.60 E+13$ \\
\hline Te-132 & $4.03 E+14$ \\
\hline $\mathrm{Xe}-131 \mathrm{~m}$ & $2.67 E+13$ \\
\hline $\mathrm{Xe}-133$ & $4.58 E+15$ \\
\hline $\mathrm{Xe}-133 \mathrm{~m}$ & $1.56 E+14$ \\
\hline $\mathrm{Xe}-135$ & $1.51 E+15$ \\
\hline $\mathrm{Xe}-135 \mathrm{~m}$ & $1.91 E+14$ \\
\hline $\mathrm{Xe}-138$ & $3.39 E+09$ \\
\hline Y-90 & $3.01 E+11$ \\
\hline Y-91 & $8.10 E+12$ \\
\hline Y-91m & $3.75 E+13$ \\
\hline
\end{tabular}

$0.18 \mathrm{~km}$. This maximum TEDE value is recorded within the restricted area. The TEDE values at distances of $5.0 \mathrm{~km}$ and beyond, where public occupation is likely to be found, are far below the annual regulatory limits of $1 \mathrm{mSv}$ from public exposure in a year even in the event of worst-case scenario as set in IAEA Safety Standard No. GSR Part 3; no action related specifically to the public exposure is required.

The results from all the simulation show that the emission is towards the north-east from the release point. 


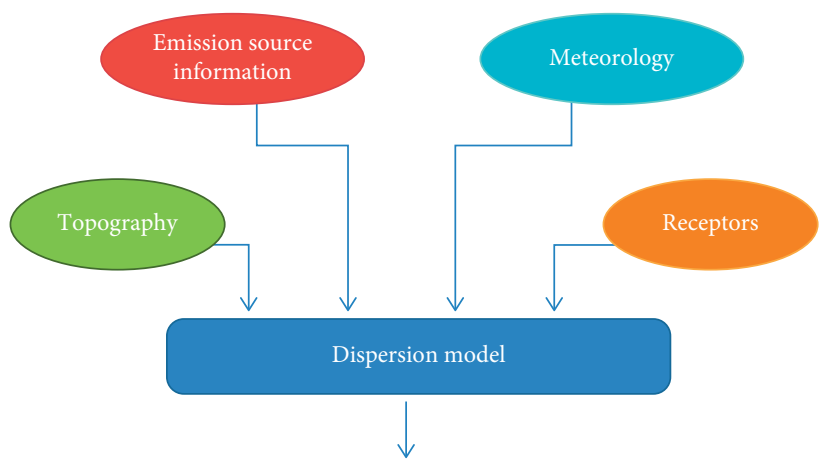

Atmospheric concentration at receptors

Figure 1: Flowchart of the simulation process of the HotSpot 3.0 code.

TABle 2: Downwind distance and other plume parameters at different arrival time intervals.

\begin{tabular}{|c|c|c|c|c|c|c|c|}
\hline $\begin{array}{l}\text { Distance } \\
(\mathrm{km})\end{array}$ & $\begin{array}{l}\text { TEDE } \\
(\mathrm{Sv})\end{array}$ & $\begin{array}{l}\text { Respiratory time-integrated } \\
\text { air concentration }\left(\mathrm{Bq}-\mathrm{sm}^{-3}\right)\end{array}$ & $\begin{array}{c}\text { Ground surface } \\
\text { deposition }\left(\mathrm{kBqm}^{-2}\right)\end{array}$ & $\begin{array}{c}\text { Ground shine } \\
\text { dose rate }\left(\mathrm{Svh}^{-1}\right)\end{array}$ & $\begin{array}{c}\text { Arrival time } \\
\text { (hr: } \min )\end{array}$ & $\begin{array}{l}\text { Inhalation } \\
\text { (Sv) }\end{array}$ & $\begin{array}{l}\text { Submersion } \\
\text { (Sv) }\end{array}$ \\
\hline 0.010 & $0.0 E+00$ & $0.0 E+00$ & $0.0 E+00$ & $0.0 E+00$ & $<00: 01$ & $0.0 E+00$ & $5.44 E-29$ \\
\hline 0.030 & $2.9 E-16$ & $3.8 E-04$ & $2.7 E-09$ & $8.3 E-18$ & $<00: 01$ & $3.76 E-17$ & $9.58 E-18$ \\
\hline 0.050 & $1.2 E-05$ & $6.8 E+06$ & $1.2 E+02$ & $3.8 E-07$ & $<00: 01$ & $6.77 E-07$ & $1.70 E-07$ \\
\hline 0.100 & $1.2 E-01$ & $5.9 E+10$ & $1.2 E+06$ & $3.8 E-03$ & $<00: 01$ & $5.82 E-03$ & $1.44 E-03$ \\
\hline 0.180 & $3.7 E-01$ & $1.9 E+11$ & $3.8 E+06$ & $1.2 E-02$ & $00: 01$ & $1.87 E-02$ & $4.56 E-03$ \\
\hline 0.200 & $3.6 E-01$ & $1.8 E+11$ & $3.7 E+06$ & $1.2 E-02$ & $00: 01$ & $1.84 E-02$ & $4.46 E-03$ \\
\hline 0.300 & $2.4 E-01$ & $1.3 E+11$ & $2.5 E+06$ & $7.7 E-03$ & $00: 02$ & $1.25 E-02$ & $3.00 E-03$ \\
\hline 0.500 & $9.9 E-02$ & $5.4 E+10$ & $1.0 E+06$ & $3.1 E-03$ & $00: 04$ & $5.37 E-03$ & $1.25 E-03$ \\
\hline 0.700 & $5.0 E-02$ & $2.8 E+10$ & $5.1 E+05$ & $1.6 E-03$ & $00: 05$ & $2.80 E-03$ & $6.37 E-04$ \\
\hline 1.000 & $2.3 E-02$ & $1.3 E+10$ & $2.4 E+05$ & $7.3 E-04$ & $00: 08$ & $1.36 E-03$ & $3.00 E-04$ \\
\hline 1.500 & $9.8 E-03$ & $5.7 E+09$ & $9.7 E+04$ & $3.0 E-04$ & $00: 12$ & $5.82 E-04$ & $1.25 E-04$ \\
\hline 2.000 & $5.2 E-03$ & $3.1 E+09$ & $5.1 E+04$ & $1.6 E-04$ & $00: 16$ & $3.17 E-04$ & $6.66 E-05$ \\
\hline 3.000 & $2.1 E-03$ & $1.3 E+09$ & $2.1 E+04$ & $6.3 E-05$ & $00: 25$ & $1.35 E-04$ & $2.72 E-05$ \\
\hline 4.000 & $1.2 E-03$ & $7.1 E+08$ & $1.1 E+04$ & $3.3 E-05$ & $00: 33$ & $7.37 E-05$ & $1.44 E-05$ \\
\hline 5.000 & $7.2 E-04$ & $4.4 E+08$ & $6.7 E+03$ & $2.0 E-05$ & $00: 41$ & $4.62 E-05$ & $8.74 E-06$ \\
\hline 7.000 & $3.5 E-04$ & $2.2 E+08$ & $3.2 E+03$ & $9.4 E-06$ & $00: 58$ & $2.29 E-05$ & $4.11 E-06$ \\
\hline 10.000 & $1.6 E-04$ & $1.0 E+08$ & $1.4 E+03$ & $4.1 E-06$ & $01: 23$ & $1.09 E-05$ & $1.83 E-06$ \\
\hline 20.000 & $3.8 E-05$ & $2.4 E+07$ & $3.2 E+02$ & $8.3 E-07$ & $02: 47$ & $2.62 E-06$ & $3.65 E-07$ \\
\hline 30.000 & $1.6 E-05$ & $1.0 E+07$ & $1.3 E+02$ & $3.1 E-07$ & $04: 11$ & $1.14 E-06$ & $1.36 E-07$ \\
\hline 50.000 & $5.4 E-06$ & $3.3 E+06$ & $4.1 E+01$ & $8.7 E-08$ & $06: 59$ & $3.98 E-07$ & $3.70 E-08$ \\
\hline
\end{tabular}

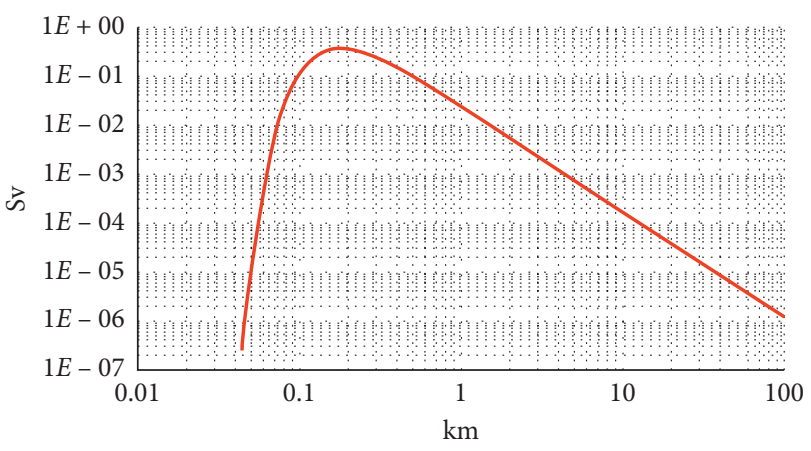

Figure 2: TEDE (Sv) as a function of downwind distance from the release point in stability class $\mathrm{A}$.

The areas that fall within the plume contour line (path) of the emission (TEDE) include parts of the western region of Ghana: from Axim towards Isakro. The direction of emission

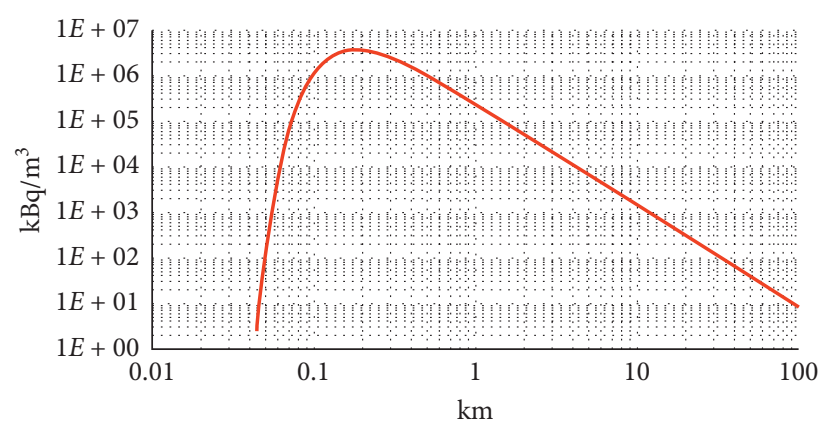

FIgURE 3: Plume centreline ground deposition of radionuclides as a function of downwind distance in stability class A.

and areas that are affected by the plume contour line (path) of the radionuclide emission are shown in Figure 4.

The maximum respiratory time-integrated air concentration and the ground deposition values of $1.9 E+11 \mathrm{~Bq}-\mathrm{s} / \mathrm{m}^{3}$ 


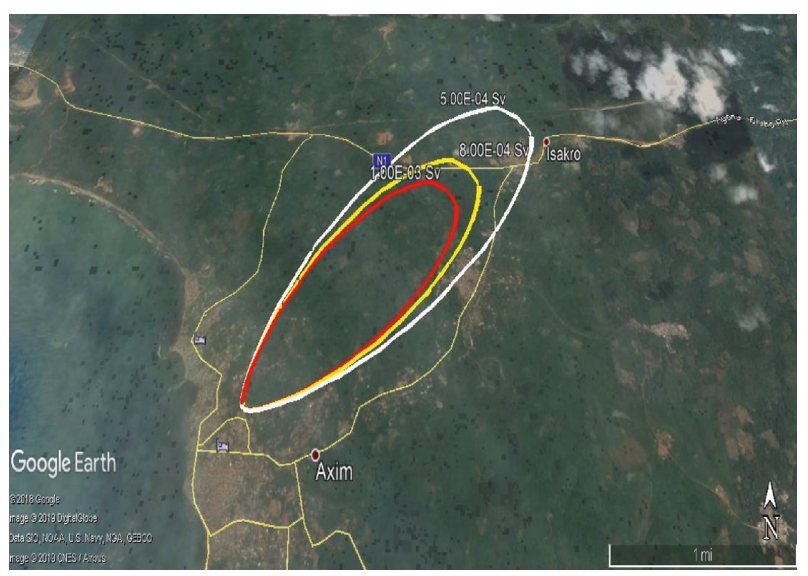

FIgURE 4: Plume contour showing the direction of emission and areas that fall within the path of the radionuclide emission.

and $3.8 E+06 \mathrm{kBq} / \mathrm{m}^{2}$, respectively, occurred at $0.18 \mathrm{~km}$ at an arrival time of about one minute $(1 \mathrm{~min})$. At the $5 \mathrm{~km}$ distance downwind, the respiratory time-integrated air concentration and the ground deposition concentration values of $4.4 E+08$ $\mathrm{Bq}-\mathrm{s} / \mathrm{m}^{3}$ and $6.7 E+03 \mathrm{kBq} / \mathrm{m}^{2}$ are recorded at an arrival time of 41 minutes.

TEDE contour plot and plume contour ground deposition distribution under the plume are shown by Figures 5 and 6, respectively, for stability class $\mathrm{A}$ and wind speed of $1.5 \mathrm{~m} / \mathrm{s}$. From Figure 5, it can be seen that three regions with the areas of 5.6, 6.7 , and $9.8 \mathrm{~km}^{2}$ have been marked with dose contours of $1.00 E-03,8.00 E-04$, and $5.00 E-04$ Sv. Also, in Figure 6, three regions with the areas of 12,69 , and $359 \mathrm{~km}^{2}$ have been marked with deposition contours of $3.70 E+03$, $3.70 E+02$, and $3.70 E+01 \mathrm{kBq} / \mathrm{m}^{2}$. The TEDE and plume contour ground deposition distribution propagate away from the source of release as a function of downwind distance. The red-coloured area depicts higher dose risk for personnel and population; the green and blue areas are less risky compared with the red area. Depending on the above results and analysis, the calculated TEDE in distances beyond $5.0 \mathrm{~km}$ is below the maximum public dose limit of $1.0 \mathrm{mSv}$ proposed by ICRP 103 [18], thus reducing the risk for serious hazards for the personnel and population with no action related specifically to the public exposure is required. The released radionuclides might be transported to long distances but will not have any harmful effect on the public.

Several pathways are available for the radiation absorptions; for example, TEDE includes the plume passage inhalation and submersion and ground shine, shown in Table 2. It is evidently clear that the plume passage inhalation is the biggest contributor among them. Furthermore, the CEDE is seen to be primarily produced by the internal material due to inhalation.

4.2. Organ CEDE Results and Analysis. CEDE describes the committed dose equivalent, which includes dose equivalents for internal body organ or tissues, which have absorbed radiation over a period of 50 years after the intake of radioactive material. HotSpot calculates CEDE by integrating

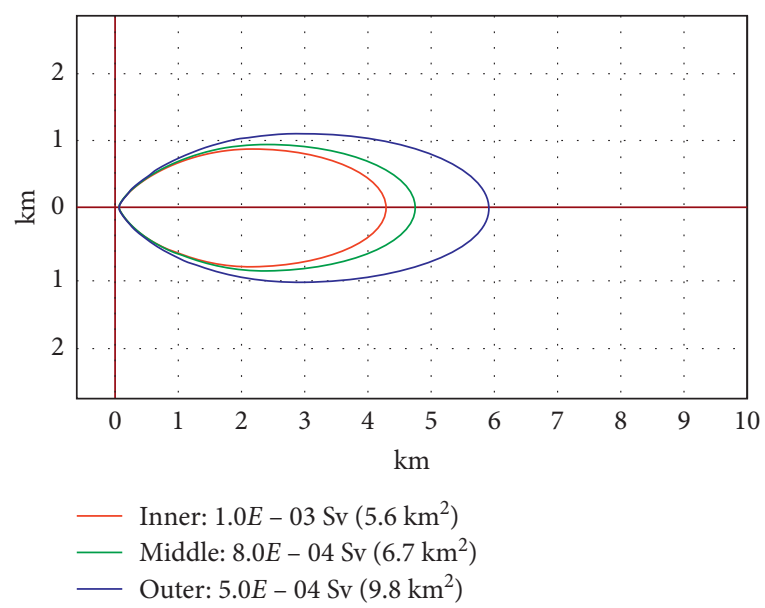

FIgURE 5: TEDE contour plot for stability class A.

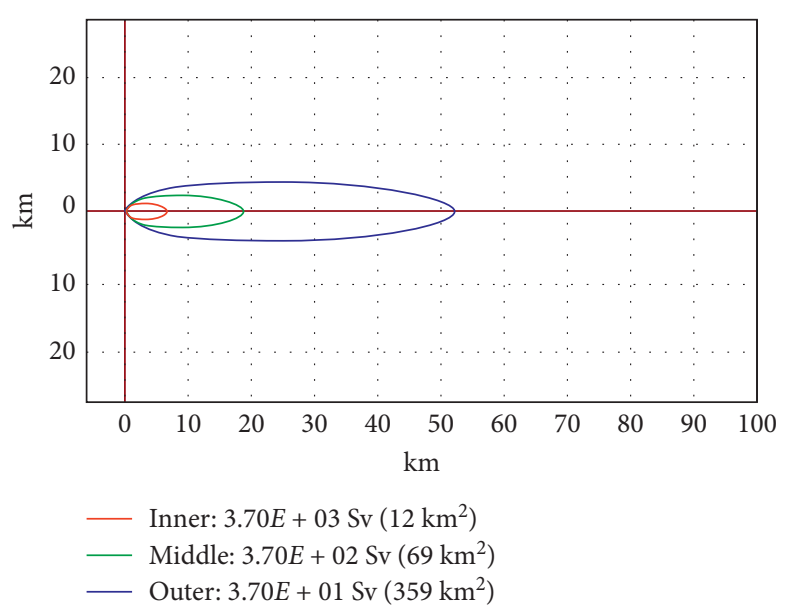

FIgURE 6: Plume contour ground deposition distribution for stability class $\mathrm{A}$.

the committed dose equivalents throughout 50 years for different tissues and organs of the body, and an appropriate multiplication factor $W_{\mathrm{T}}$ has been used for each committed dose equivalent.

The distributions of CEDE to different organs as a function of downwind distance are shown in Figures 7 and 8. The organ with the highest CEDE value is the skin as seen in Figure 7 , with a maximum CEDE of about $1.70 \mathrm{~Sv}$ at the downwind distance of $0.18 \mathrm{~km}$. Thyroid and surface bone follow in sequence. Since the skin, thyroid, and surface bone CEDEs are far larger than those of the other organs, Figure 8 is produced to show clearer plots for the other organs' CEDE as a function of downwind distance. In terms of magnitude of the CEDE, from Figures 7 and 8, skin tops the list, followed by thyroid, surface bone, muscle, and testes. The maximum CEDEs of thyroid, surface bone, muscle, and testes are about $7.10 E-01,5.50 E-01,3.70 E-01$, and $3.70 E-01 \mathrm{~Sv}$ at the downwind distance of $0.18 \mathrm{~km}$, respectively. It can be deduced that these five organs are more radiation-sensitive to the radionuclides emitted due to the accident than the others. 


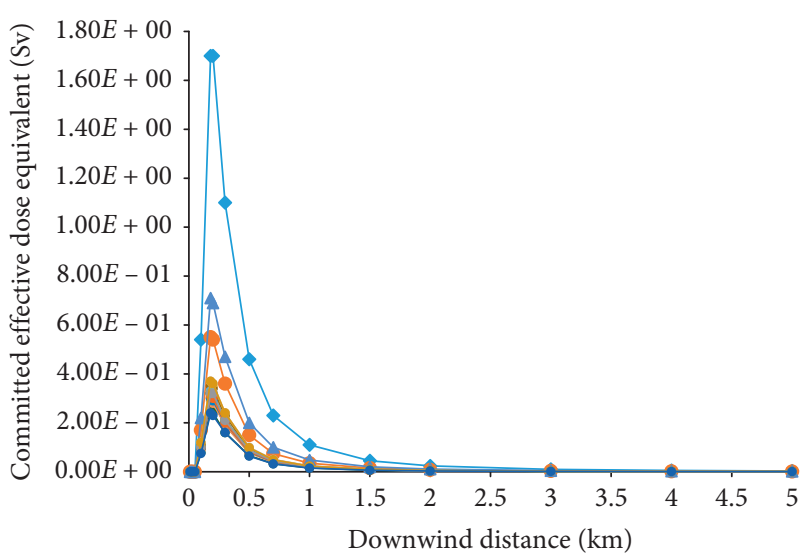

$\begin{array}{ll}\rightarrow \text { Skin } & \rightarrow \text { Oesophagus } \\ \rightarrow \text { Breast } & \rightarrow \text { Thyroid } \\ \rightarrow \text { Kidneys } & \rightarrow \text { SI wall } \\ \rightarrow \text { Red marrow } & \rightarrow \text { Uterus } \\ \rightarrow \text { LLI wall } & \rightarrow \text { Spleen } \\ \rightarrow \text { Brains } & \rightarrow \text { Thymus } \\ \rightarrow \text { Adrenals } & \rightarrow \text { Lung } \\ \rightarrow \text { Muscle } & \rightarrow \text { Stomach wall } \\ \rightarrow \text { Surface bone } & \rightarrow \text { Testes } \\ \rightarrow \text { ULI wall } & \rightarrow \text { Liver } \\ \rightarrow \text { Pancreas } & \rightarrow \text { Bladder wall } \\ \rightarrow \text { Ovaries } & \end{array}$

Figure 7: Organ CEDE profile due to 49 nuclides from the source term versus downwind distance (LLI: lower large intestine; SI: small intestine; ULI: upper large intestine).

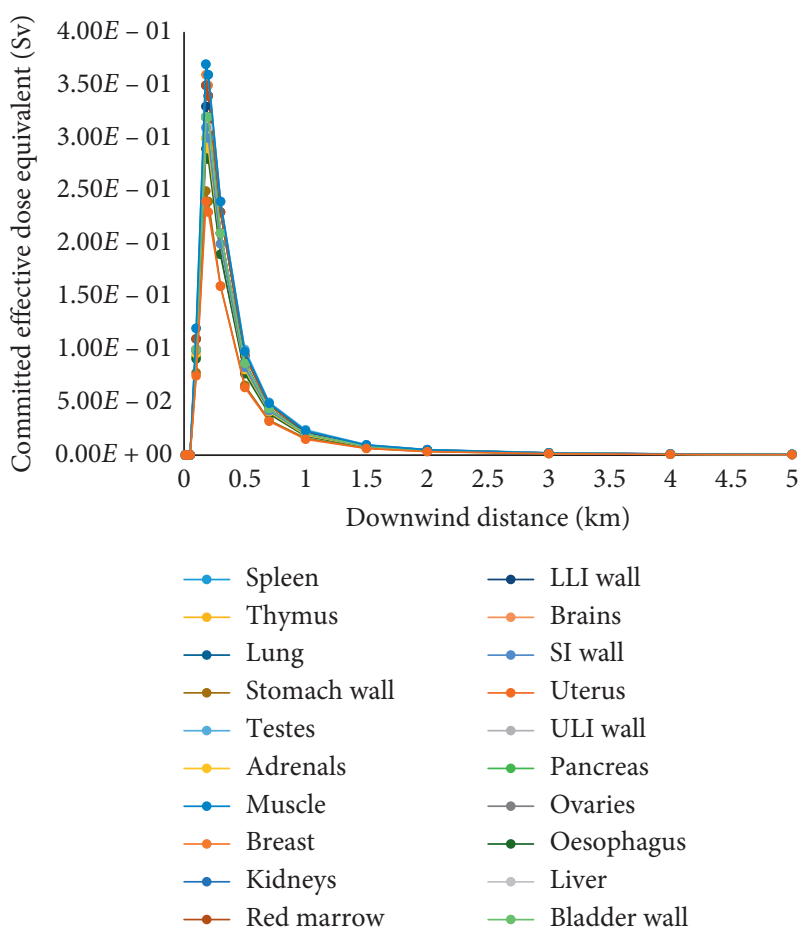

Figure 8: Organ CEDE profile due to 49 nuclides from the source term versus downwind distance, not including skin, thyroid, and surface bone (LLI: lower large intestine; SI: small intestine; ULI: upper large intestine).

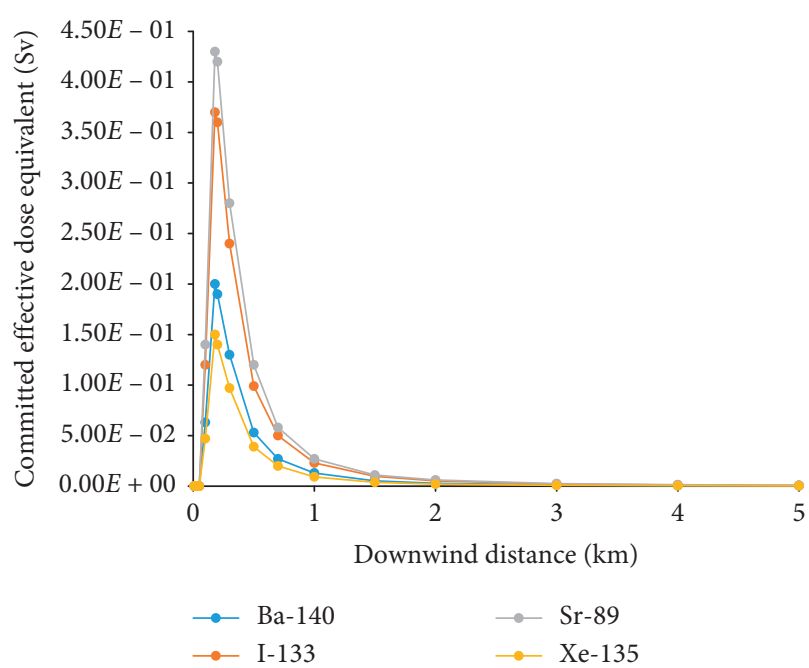

FIGURE 9: Skin CEDE profile versus downwind distance.

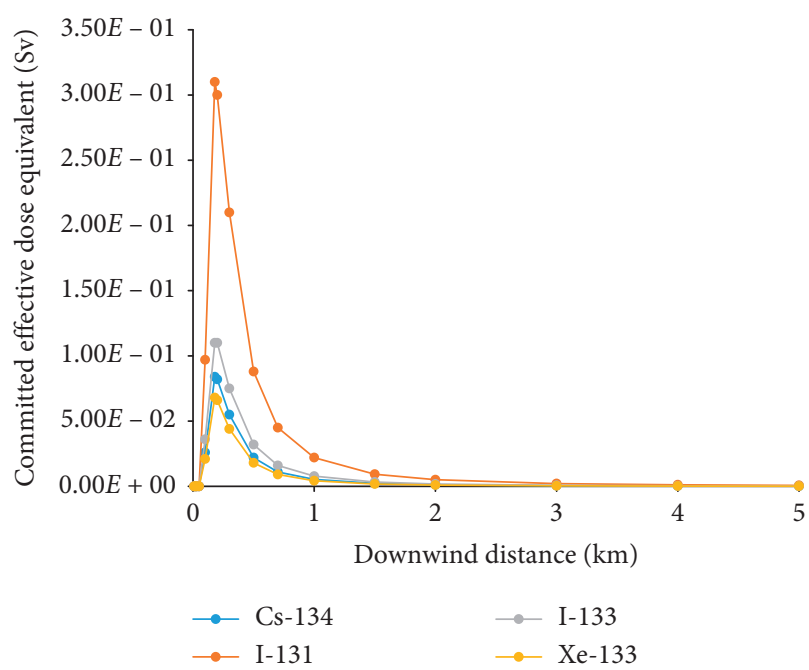

Figure 10: Thyroid CEDE profile versus downwind distance.

From Figure 9, it can be seen that the main radionuclides contributing to the skin CEDE are Sr-89, I-133, Ba-140, and $\mathrm{Xe}-135$. These four radionuclides are responsible for such a CEDE plot trend; others have very little contribution. The percentages of contribution by Sr-89, I-133, Ba-140, and Xe135 are about $25.3 \%, 21.8 \%, 11.8 \%$, and $8.8 \%$, respectively, at the maximum skin CEDE.

Figure 10 shows the thyroid CEDE profile as a function of downwind distance. The main radionuclides contributing to the thyroid CEDE are I-131, I-133, Cs-134, and Xe-133, with percentages of contribution of about $43.7 \%, 15.5 \%$, $11.8 \%$, and $9.6 \%$ at the maximum CEDE, respectively.

Figure 11 also shows the surface bone CEDE profile as a function of downwind distance. The main radionuclides contributing to the lung CEDE are Xe-133, Cs-134, I-131, and I-133, responsible for $43.6 \%, 21.8 \%, 20.0 \%$, and $12.7 \%$, respectively, of the maximum CEDE.

It can likewise be seen from Figure 12 that the main radionuclides contributing to the muscle CEDE are Cs-134, 


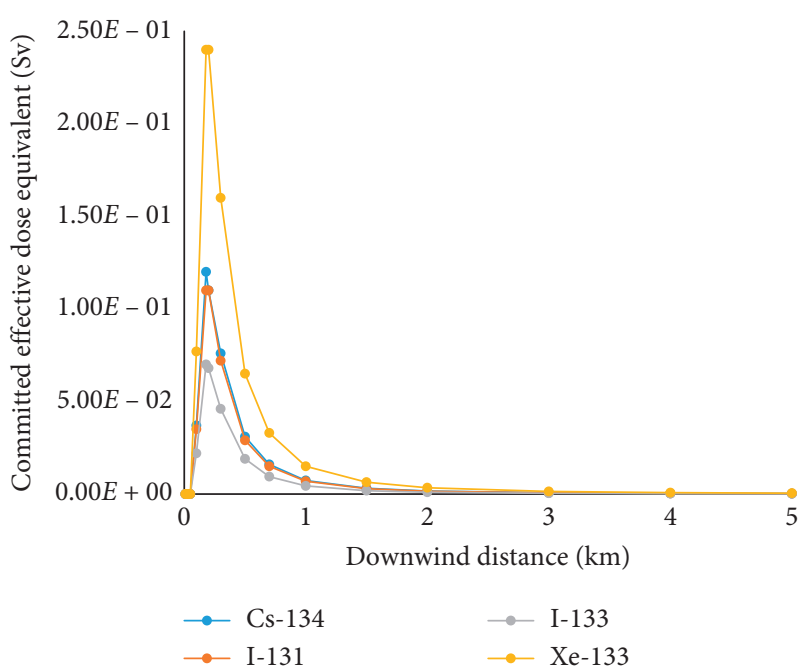

Figure 11: Surface bone CEDE profile versus downwind distance.

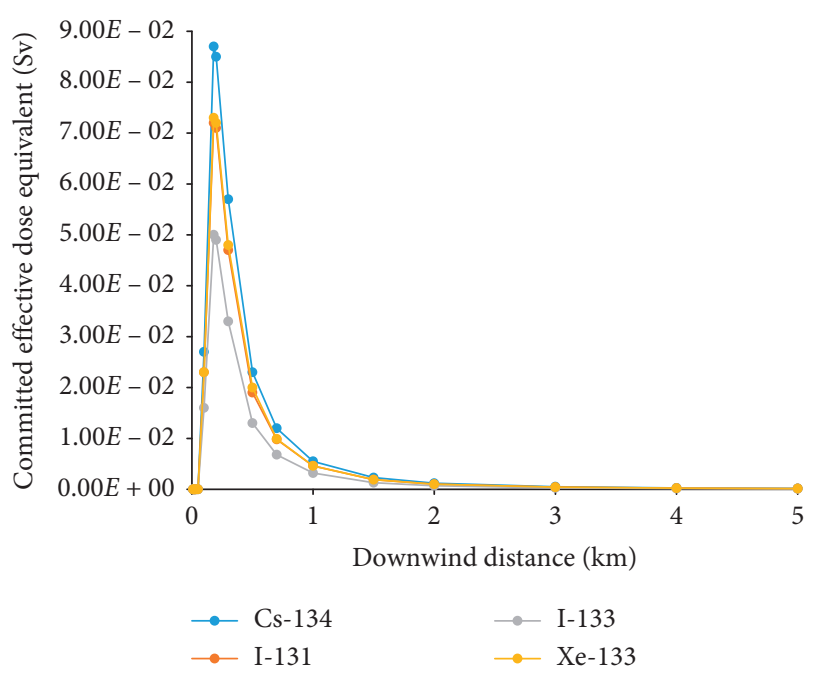

FIgure 12: Muscle CEDE profile versus downwind distance.

Xe-133, I-131, and I-133 with percentages of contribution of about $23.5 \%, 19.7 \%, 19.5 \%$, and $13.5 \%$, respectively, at the maximum CEDE.

Furthermore, Figure 13 shows that the main contributors to the testes CEDE are Cs-134, Xe-133, I-131, and I-133, responsible for about $23.7 \%, 22.7 \%, 20.0 \%$, and $13.8 \%$, respectively, of the maximum CEDE.

According to the analysis of the above results, it can be concluded that seven radionuclides, I-131, I-133, Sr-89, Cs$134, \mathrm{Ba}-140, \mathrm{Xe}-133$, and $\mathrm{Xe}-135$, are the main contributors to the CEDE.

These radionuclides undergo diverse chemical reactions when they enter the human body, thus indicating a major and serious health concern. It is therefore expedient to institute protective actions to avoid inhalation

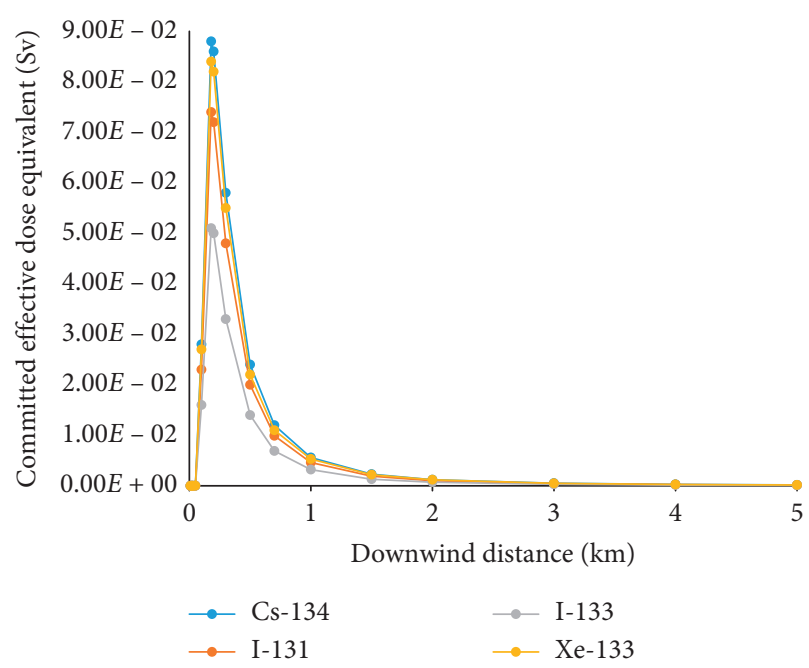

Figure 13: Testes CEDE profile versus downwind distance.

and ingestion of these radionuclides during nuclear accidents.

\section{Conclusions}

The radiation dose calculations and radiological consequences of a hypothetical accident have been performed by considering a generic VVER-1000 loss of coolant accident by using HotSpot code. According to the site-specific meteorological data used, the maximum TEDE value of $3.69 E-01 \mathrm{~Sv}$ and the maximum ground deposition value of $3.80 E+06 \mathrm{kBq} / \mathrm{m}^{2}$ occurred at $0.18 \mathrm{~km}$ from the release point. The direction of the radionuclide emission from the release point is towards the north-east. This maximum TEDE value is recorded within a distance where public occupation is restricted. The TEDE values at distances of $5.0 \mathrm{~km}$ and beyond where public occupation is likely to be found are far below the annual regulatory limits of $1 \mathrm{mSv}$ for the public even in the event of worst-case accident scenario as set in IAEA Safety Standard No. GSR Part 3 [19]; no action related specifically to the public exposure is required. It is realised that the organ with the highest value of CEDE is the skin. It was followed by the thyroid, bone surface, muscle, and testes in order of decreasing CEDE value. The contributions of 49 radionuclides were investigated, and it was realised that the radionuclides I-131, I-133, Sr-89, Cs-134, $\mathrm{Ba}-140, \mathrm{Xe}-133$, and $\mathrm{Xe}-135$ are the main contributors to the CEDE. It is recommended to take protective measures to avoid inhalation and ingestion in case of accidents, since these radionuclides could be detrimental to the health and safety of human and the environment.

\section{Data Availability}

The site meteorological and analysis code data used to support the findings of this study are included within the article. 


\section{Conflicts of Interest}

The authors declare that there are no conflicts of interest regarding the publication of this paper.

\section{References}

[1] D. Ahuja and M. Tatsutani, "Sustainable energy for developing countries," SAPI EN. S. Surveys and Perspectives Integrating Environment and Society, vol. 2, no. 1, 2009.

[2] OECD, OECD Green Growth Strategies: Energy, OECD Publishing, Paris, France, 2011.

[3] IEA, Key World Energy Statistics, IEA, Paris, France, 2012.

[4] IAEA, Site Evaluation for Nuclear Installations, International Atomic Energy Agency, Vienna, Austria, 2003.

[5] AELB, Guideline for Site Evaluation for Nuclear Power Plant, Atomic Energy Licensing Board, Selangor, Malaysia, 2011.

[6] NRA, Draft Sitting regulations for nuclear power installations in Ghana, Nuclear Regulatory Authority, Ghana, 2019.

[7] S. D. Shamsuddin, N. A. Basri, N. Omar, M. H. Koh, A. T. Ramli, and W. M. S. W. Hassan, "Radioactive dispersion analysis for hypothetical nuclear power plant (NPP) candidate site in Perak state, Malaysia," EPJ Web of Conferences, vol. 156, Article ID 00009, 2017.

[8] B. Cao, W. Cui, I. Rasheed, and Y. Chen, "Atmospheric dispersion modelling and radiological safety analysis for a hypothetical accident of liquid-fuel thorium molten salt reactor (TMSR-LF)," Bulgarian Chemical Communications, vol. 50, pp. 78-85, 2018.

[9] S. G. Homann and F. Aluzzi, HotSpot Health Physics Code, Version 3.0, User's Guide, LLNL-SM-636474, National Atmospheric Release Advisory Center, Lawrence Livermore National Laboratory, Livermore, CA, USA, 2013.

[10] B. Cao, J. Zheng, and Y. Chen, "Radiation dose calculations for a hypothetical accident in xianning nuclear power plant," vol. 2016, Science and Technology of Nuclear Installations, Article ID 3105878, 6 pages, Science and Technology of Nuclear Installations, 2016.

[11] DOE/HS-0003, Software Evaluation of Hotspot and DOE Safety Software Toolbox Recommendation, Department of Energy, Office of Health, Safety and Security, Washington, DC, USA, 2007.

[12] J. W. Healy, "Radioactive cloud dose calculation," in Atmospheric Science and Power Production (DOAE/TIC-2), D. Randerson, Ed., U.S. Department of Energy, Washington, DC, USA, 1984.

[13] D. H. Slade, "Meteorology and atomic energy," Technical Report, Technical Information Center U. S. Department of Energy, VA, USA, 1968.

[14] S. Zoras, A. G. Triantafyllou, and D. Deligiorgi, "Atmospheric stability and PM10 concentrations at far distance from elevated point sources in complex terrain: worst-case episode study," Journal of Environmental Management, vol. 80, no. 4, pp. 295-302, 2006.

[15] P. Arya, Air Pollution Meteorology and Dispersion, Oxford University Press, Oxford, USA, 1999.

[16] K. Wark, C. F. Warner, and W. T. Davis, Air Pollution: Its Origin and Control, Addison-Wesley, Boston, MA, USA, 1998.

[17] United States Nuclear Regulatory Commission, Regulatory Guide 1.183: Alternative Radiological Source Term for Evaluating Design Basis Accidents at Nuclear Power Reactors, United States Nuclear Regulatory Commission, Rockville, MD, USA, 2000.
[18] J. Valentin, "ICRP publication 103," in Annals of the ICRP, vol. 37, ICRP, Ottawa, Ontario, Canada, 2007.

[19] IAEA, "Radiation Protection and Safety of Radiation Sources: International Basic Safety Standards, General Safety Requirements," in IAEA Safety Standards Series No. GSR Part 3, International Atomic Energy Agency (IAEA), Vienna, Austria, 2014. 

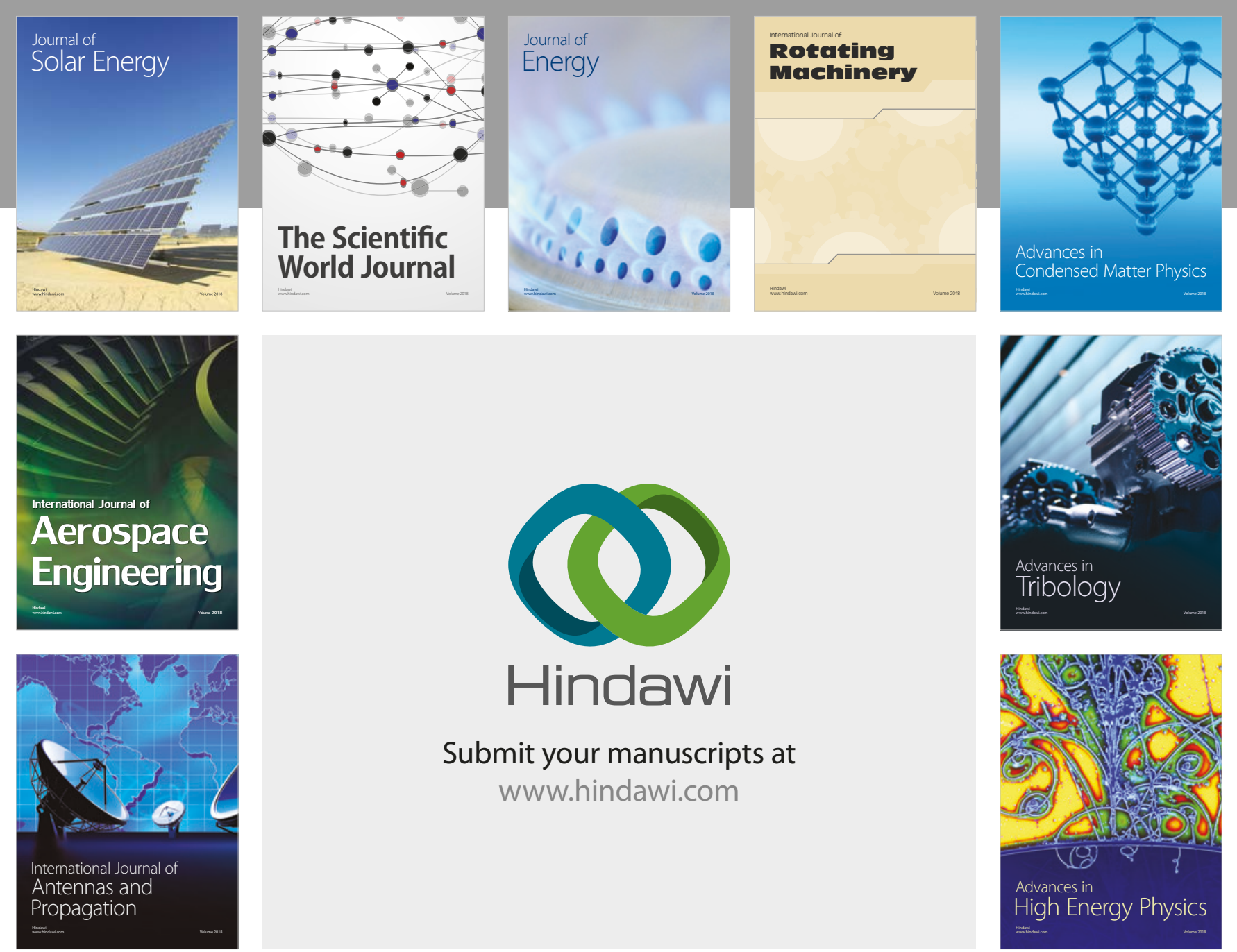

Submit your manuscripts at

www.hindawi.com
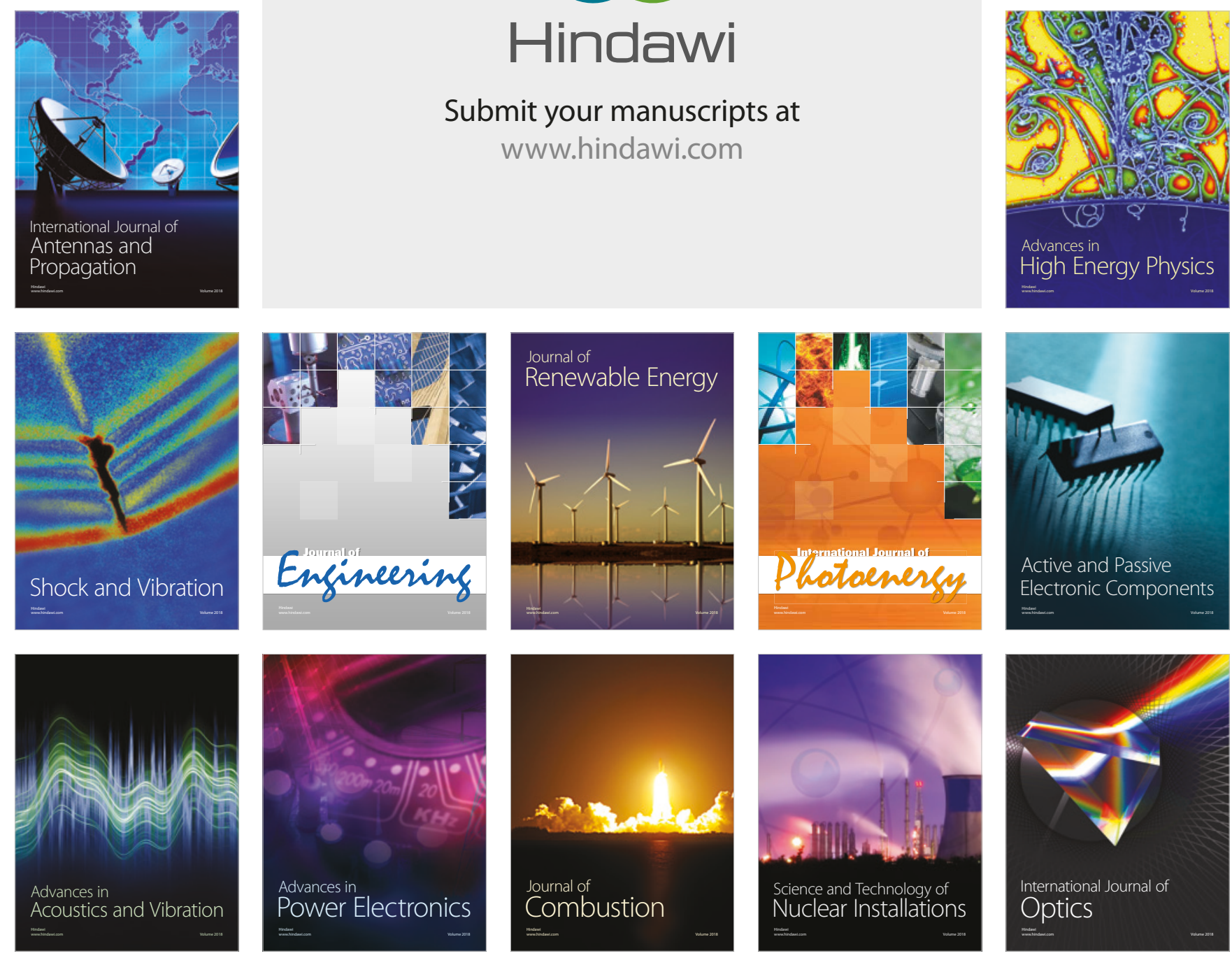